NASA Technical Memorandum 107043

AIAA-95-2398

$1 N-36$

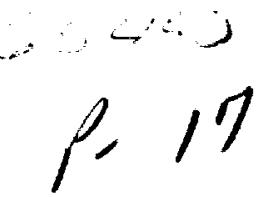

\title{
Rhenium Material Properties
}

James A. Biaglow

Lewis Research Center

Cleveland, Ohio

Prepared for the

31st Joint Propulsion Conference and Exhibition cosponsored by AIAA, ASME, SAE, and ASEE San Diego, California, July 10-12, 1995
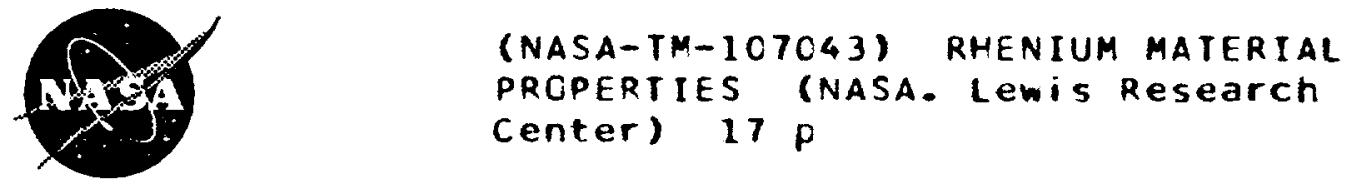


\title{
RHENIUM MATERIAL PROPERTIES
}

\author{
James A. Biaglow \\ National Aeronautics and Space Administration \\ Lewis Research Center \\ Cleveland, Ohio $\mathbf{4 4 1 3 5}$
}

\begin{abstract}
Tensile data were obtained from four different types of thenium at ambient and elevated temperatures. The four types of inenium included chemical vapor deposition (CVD) and three powder metallurgy (PM) types, i.e., rolled sheet and pressed and sintered bars, with and without hot isostatic pressure (HIP) treatment. Results revealed a wide range of values with ultimate strengths at ambient temperatures varying from $663 \mathrm{MPa}$ for CVD henium to $943 \mathrm{MPa}$ for rolled sheet. A similar spread was also obtained for material tested at $1088 \mathrm{~K}$ and $1644 \mathrm{~K}$. The wide variance observed with the different materials indicated that the menium manufacturing process, material composition and prior handling strongly dictated its properties. In addition to tensile properties, CVD, pressed and sintered material and HIP rhenium successtully completed 100 cycles of low cycle fatigue. Creep data were also obtained showing that CVD and pressed and sintered menium could sustain five hours of testing under a tension of $27.5 \mathrm{MPa}$ at $1922 \mathrm{~K}$.
\end{abstract}

\section{Introduction}

The On-Board Propulsion Branch of NASA Lewis Research Center (LeRC) and the aerospace industry are currently investigating a series of $22 \mathrm{~N}$ to $890 \mathrm{~N}$ thrust chambers (refs. 1, 2) made from rhenium material coated with iridium for oxidation protection. The longest test time on a single chamber so far has been 39 hours at NASA LeRC with a oxide coated iridium/rhenium $22 \mathrm{~N}$ chamber (ref. 3) and
6.3 hours with a fight type $440 \mathrm{~N}$ thrust chamber (ref. 4). The operating temperature of these chambers were in excess of 2000 $K$ yielding 8 percent improvement in performance over conventional chambers. This excellent performance means less film cooling, greater life, and increased payloads into orbit with space vehicles using menium thrust chambers. However, the lack of reliable material properties data are hindering their full acceptance. Current properties data are very sparse and scattered throughout the literature. Furthermore, property data are often reported for forms of rhenium that are not used for chamber manufacture or where the material history is not reported. Property data for various forms of ihenium are reported in references 5 to 8 . The data they report are within the scatter of the results obtained here.

This paper presents the material properties of rhenium in manufacturing forms that were considered prime candidates for thrust chamber development. Reproducible data, obtained in controlled environments, are required before thenium can be considered as a viable candidate for thrust chamber development. In particular the tensile strength, low cycle tatigue, and creep properties were determined for up to four different types of manufactured inenium. The four different types of inenium included: chemical vapor deposition (CVD), and powder metallurgy (PM) in the forms of rolled sheet, pressed and sintered bars, and hot isostatic pressure (HIP) treated material. Using these four material varieties, a program plan was developed to determine the properties of 59 rhenium samples. This 
large number of test samples was selected to insure that any large variation from established trends could easily be identified and further investigated for their deviation.

\section{Background}

Current on-board propulsion systems use a high temperature alloy C-103 with a disilicide oxide coating. These chambers are limited by wall temperature to $1593 \mathrm{~K}$ operation. In order to maintain wall temperature below this limit, 30 to 40 percent of the tuel is usually required as a film cooling barrier. This large film cooling requirement extracts a penalty in performance since operation of the chamber is kept below levels that would yield optimum specific impulse. A leading candidate to replace $\mathrm{C}-103$ is thenium with iridium used as an oxidation resistant coating. Rhenium has a high melting temperature of $3453 \mathrm{~K}$ along with high temperature strength and thermal shock resistance. Performance gains of up to 20 seconds specific impulse are demonstrated with rockets using earth storable fuel and menium chambers (ref. 9). These gains are achieved through designs which eliminated film cooling and improved combustion efficiency. CVD and PM are two of the prime material preparation techniques for this ihenium material. The successtul performance of these materials generates a need to know their physical properties in more detail. These material data are especially important in the design process for determining the durability of thrusters during launch vibration and repeated firing on-orbit.

In order to generate the needed information, LeRC conducted a thenium materials development program under the Space Storable Rocket Technology Program (SSRT) with TRW and a parallel effort inhouse. The SSRT program investigated the properties of 37 samples made by CVD and PM produced from pressed and sintered material. LeRC investigated 22 samples, including CVD, HIP, and rolled sheet inenium.
CVD henium The CVD material used in this investigation was obtained from Ultramet. The CVD process produces a thick structural deposit by the chemical reaction of a vapor at a surface on a heated substrate. To form structures of $0.132 \mathrm{~cm}$ thickness required in this study, the deposition was done in several layers The first layer formed at nucleation sites. Atter the substrate is fully covered growth continued on the crystal faces of the deposit until the desired thickness was reached. The process was then halted as many times as needed to prevent large crystal formation. The surface was machined smooth and the process restarted until the final desired thickness was reached.

Powder Metalluray All three types of powder metallurgy samples were made from a high green strength 200 mesh powder that was 99.99 percent pure. Rhenium Alloys Inc. provided all the PM samples. The pressed and sintered bars measured 95 to 96.3 percent dense. The rolled sheet was obtained from an ingot that was rolled in the longitudinal direction to produce a sheet that was nominally $8 \mathrm{~cm}$ wide by $38 \mathrm{~cm}$ long and $0.16 \mathrm{~cm}$ thick. Density of the rolled sheet was greater than 99 percent. The HIP treated samples were obtained from the outer perimeter of a large cylindrical ingot that was used to manufacture a $440 \mathrm{~N}$ thrust chamber. Density of these samples was also greater than 99 percent.

\section{Test Procedure}

All sample bars, both those required in the SSRT program and LeRC in-house investigations were sent for testing to Energy Material Testing Laboratory (EMTL). This was done to assure consistency in test procedures and measured results. The flat bars which measured approximately $2.2 \mathrm{~cm}$ wide by $10.1 \mathrm{~cm}$ long, were electron discharged machined (EDM) using copper wire into the dog bone shape shown in Figure 1. The dog bone samples were then acid scrubbed to remove any melt or recrust area formed by machining. The test pieces were then acid washed several times to 
remove any contaminates. Any test piece not annealed by the manufacture was then annealed. For the LeRC in-house samples, only the HIP material had to be annealed at $1922 \mathrm{~K}$ for 30 minutes. Data, from thenium material that has been annealed, are important as it simulates the condition of the thrust chamber after hot rocket acceptance testing. After annealing, Rockwell hardness measurements were made and were recorded for the LeRC samples in Table I. All samples were then weighed, photographed and visually inspected before testing. Test samples were placed in a chamber that was first purged with argon which was then out gassed until a oxygen sensor dropped below 50 ppm. Samples to be tested were heated at a rate of $13 \mathrm{~K}$ per minute until target temperature was reached. Tensile testing of all samples was then conducted at a load rate cross head velocity of $0.13 \mathrm{~cm}$ per minute until the sample failed. Upon the occurrence of failure all data were saved and the sample redimensioned to determine any length change due to plastic deformation. The testing facility, EMTL then prepared and submitted a detailed report to LeRC (ref. 10).

\section{Test Results}

The data for rhenium tensile samples are presented in Table II and includes values for unannealed and annealed bars. Test data are presented for tensile yields of 0.2 and 0.5 percent ,ultimate strength, elastic modulus, and percent strain to failure ratio. Figure 2 plots ultimate strength and the 0.2 percent yield data. Comparison of the data shows that menium tensile strength has a wide range of values based on the anneal, the method of material preparation, and the test temperature. For ease of comparison, powder metallurgy results are plotted separately in Figure 3 and CVD results in Figure 4. In addition to tensile data, creep data is presented in Table III for CVD and PM pressed and sintered rhenium while low cycle fatigue data is presented for CVD, PM pressed and sintered and HIP rhenium in Table IV.
Rolled Sheet. From Figure 2 it is seen the rolled sheet produced some of the highest as well as the most consistent data of all the menium materials tested. Maximum yield strength at room temperature was 590.1 $\mathrm{MPa}$ with a ultimate strength of $943.1 \mathrm{MPa}$, elastic modulus $434.4 \mathrm{GPa}$ and a strain to tailure of 17.2 percent. When the test temperature was raised to $1644 \mathrm{~K}$, yield was reduced to $370.1 \mathrm{MPa}$, ultimate to 443.3 MPa with a elastic modulus of 195.1 $\mathrm{GPa}$ and a strain to failure ratio of 1.38 percent. The rolled sheet was the only PM material that showed the typical characteristic of decreasing yield strength with increasing temperature.

Electron microscope photographs in Figure 5 further detail some of the unique characteristics of rolled rhenium. Figure 5 shows that failure was preceded by elongation or necking of the specimen followed by rupture. In several cases this failure is along a 45 degree angle with the load. This type of failure is characteristic of ductile materials and is a good indication that intergranular shear forces are primary responsible for tailure. Scanning electron microscope (SEM) photographs taken at times sixty magnification (Figure 6) indicate that failure is due to intergranular ductile rupture at room temperature with some dimple rupture evident at the $1644 \mathrm{~K}$ temperature. Observations of the samples after testing showed that three of them exhibited signs of plastic deformation on the sample surface due to material yield. This behavior was observed outside of the nupture location No low cycle fatigue or creep tests were conducted with the rolled sheet.

Pressed and sintered The pressed and sintered samples were investigated under the SSRT program and are reported in detail in Reference 11. Results presented here are meant to summarize the materials performance and show how it compared to the other forms of manufactured inenium samples. The pressed and sintered PM material produced the lowest ultimate strength levels of any PM sample tested. Figure 4 shows that yield strengths were below any other tested inenium sample. 
These low values were attributed to the low density of the material, 95 to 96 percent. Table II shows that unannealed test samples have lower ultimate strength than annealed. This difference was opposite to what was anticipated and was attributed to repressing of some of the samples after sintering and annealing. This repressing or straightening was done on samples that showed signs of being warped and as a result added work hardening to the material. The sintered PM was one of three types of menium that was tested for low cycle fatigue as shown in Table IV. Results indicated that in tension and compression PM sintered thenium had sufficient strength to successfully sustain 100 low fatigue cycles based upon yield strengths. Another sample of this same material completed a five hour creep test at $1922 \mathrm{~K}$ and 27.5 $\mathrm{MPa}$. The creep test temperature and pressure were values selected that represent the worst case scenario for $\mathbf{4 4 0}$ to $880 \mathrm{~N}$ thrust class rockets.

HIP The HIP treated PM rhenium samples were second only to the rolled sheet in ultimate strength when evaluated at ambient and $1088 \mathrm{~K}$. When the test temperature reached $1644 \mathrm{~K}$ values of ultimate strength as with sintered PM were below that of the CVD samples. Yield strengths at all temperatures were the second lowest of all tested material. The HIP material also exhibited the unique property of increased yield strength as the test temperature was raised from ambient to $1088 \mathrm{~K}$ (Figure 3 ).

Examination of the nuptured samples in Figure 5 shows that in all cases the break produced almost no reduction or necking of the sample. This lack of necking and the transverse breaks are a good indication that HIP thenium is more brittle in nature than was seen in the previous samples. Figure 6 shows the HIP menium had a very fine almost sand like structure rather than a stringy or rock candy like texture. The sand like structure indicates that failure was through transgranular rupture rather than intergranular that was characteristic of the other PM materials. PM HIP material thus behaves more like a structure that fractures across a fine grain surface. Observations of the samples after testing showed no noticeable surface plastic deformation. Table IV shows that HIP thenium possesses the ability to withstand 100 low fatigue cycles at both $1088 \mathrm{~K}$ and $1644 \mathrm{~K}$. The one sample that failed to reach this goal was accidentally pretested to $400 \mathrm{MPa}$ and inaddition was warped across the width direction. This sample was warped due to stress relieving after annealing and was sufficient to prevent correct alignment in the test apparatus.

CVD Chemical vapor deposition results are presented for tensile data obtained under the SSRT program and the LERC in-house effort. The SSRT data are reported in detail in Reference 11. The SSRT and LERC samples were obtained from the same manufacturing run. Since both sets of material were from the same nu and identical procedures were used to obtain tensile data, they are treated in this report as if coming from one source. Results of tensile tests indicate good agreement with yield strengths at ambient conditions but a wide variation as the temperature was raised to $1088 \mathrm{~K}$ and $1644 \mathrm{~K}$. The CVD samples also showed the unique property of increased yield strength, as noted with PM material, when the temperature was increased from ambient to $1088 \mathrm{~K}$. Ultimate strengths showed good agreement at ambient and $1088 \mathrm{~K}$ but a wide variation at $1644 \mathrm{~K}$. Figure 5 and 6 reveal some of the unique characteristics of the CVD material as far as rupture and grain structure. In Figure 5 , in the majority of cases there is a noticeable elongation in the area of the rupture followed by a very jagged and irregular tearing type break across the sample. This type of very coarse nupture reveals several layers of the CVD material indicating that rupture points occurred in different planes. The elongation of the samples and the ragged angular breaks identified the CVD material as being ductile in nature. It is this elongation 0.4 percent for sample 6-CVD and 3.1 percem 5-CVD that is responsible for the large spread in data at $1644 \mathrm{~K}$ (Figure 4). In addition to the elongation and jagged breaks, Figure 6 
shows that CVD material had a different grain structure than was seen with any of the other manufactured rhenium samples. The grain structure consisted more of large columnar or rock candy surface and that failure was by intergranular fracture modes. As with the SSRT samples, there was no indication of laminar separation. Observations of the samples after testing showed that all but one had numerous small cracks on the edge of the test piece. These cracks extended only slightly into the gage section. No noticeable plastic deformation was observed with the CVD samples.

The CVD material was also tested for low cycle fatigue and the ability to withstand creep. CVD rhenium showed the ability to complete 100 cycles of $137.9 \mathrm{MPa}$ tension and $68.9 \mathrm{MPa}$ compression but suffered from plastic deformation. The CVD menium also showed no creep failure at $1922 \mathrm{~K}$ and 27.5 MPa.

\section{Summary/Conclusions}

(1) Tensile tests of four different menium materials revealed a wide range of values that strongly suggest menium strength is process controlled and that selection of a thenium manufacturing process and prior handling will strongly dictate its properties.

(2) HIP rhenium demonstrated some of the highest levels of strength along with the ability to withstand 100 low fatigue cycles based upon yield strengths. Its failure was characterized by a sharp brittle like break.

(3) Rolled sheet demonstrated the highest level of strength. Its failure was by intergranular and dimpled rupture indicative of a ductile material.

(4) CVD material demonstrated a wide range of tensile strengths failing by intergranular shear forces. Tensile data was within the scatter of previously reported results.

(5) Pressed and sintered rhenium showed the lowest level of strength for PM samples tested but was sufficiently strong enough to pass the low cycle fatigue and creep tests.

\section{REFERENCES}

1. Schneider, S. J., "HighTemperature Thruster Technology For Spacecraft Propulsion", IAF-01-254, 42ND Congress of the International Astronautical Federation, Montreal, Canada, October 5,1991 .

2. Schneider, S. J., Low Thrust Chamber Rocket Technology", IAF-920669, 43ND Congress of the International Astronautical Federation, Washington, DC., August 1992.

3. Reed B.D., "Long Life Testing of Oxide Coated Iridium/Rhenium Rockets", AlAA 95-2401, San Diego, CA., July 1995.

4. Jassowski D. M. "Advanced Small Rocket Chambers, Option 3", NASA CR 195455, 1993.

5. Southern Research Institute "High Temperature Tensile Evaluation of Pressed and Sintered Rhenium", February 1994.

6. Svedberg, R. C. and Bowen, W. W., "High Temperature Creep and Tensile Properties of Chemically Vapor-Deposited Rhenium", Report No. HEDL-SA-2695-FD, Metallurgical Coatings and Process Technology Conference, San Diego, CA, April 1982.

7. Horak, J. A., and Kangilaski M., "Effects of Irradiation on the Tensile Properties of Rhenium", ORNLTM-12360, U.S.Department OF Energy, April 1993.

8. Bryskin, B. D., "Evaluation of Properties and Special Features for HighTemperature Application of Rhenium", 278291, Ninth Symposium, Space Nuclear Power Systems, Albuquerque, NM, 1992.

9. Chazen, M.L., Mueller, T. and Rust, T., "Space Storable Rocket Technology Program", Option 1 Final Report, NASA Lerc, CR-191171, August 1993.

$\begin{array}{llr}\text { 10. Energy } & \begin{array}{c}\text { Materials } \\ \text { Maboratory, }\end{array} & \begin{array}{c}\text { Testing } \\ \text { Property }\end{array}\end{array}$


Evaluations, Tensile and Low Cycle Fatigue Testing of Rhenium at Room and Elevated Temperatures", Final Report 1705, NASALeRC C- 79086-C, March, 1995.

11. Chazen, M. L., "Materials Property Test Results of Rhenium", AIAA 95-2938, San Diego, CA., July 1995. 
TABLE I. RHENIUM HARDNESS RESULTS

\begin{tabular}{|l|l|l|}
\hline MATERIAL & SAMPLE & $\begin{array}{l}\text { ROCKWELL “B” } \\
\text { HARDNESS }\end{array}$ \\
\hline \multirow{3}{*}{ PM ROLIED SHEET } & RS-1 & 105 \\
& RS-2 & 105 \\
& RS-3 & 103 \\
& RS-4 & 104 \\
& RS-5 & 105 \\
& RS-6 & 102 \\
CHEMICAL VAPOR & 1-CVD & 99 \\
DEPOSITION & 2-CVD & 99 \\
& 3-CVD & 102 \\
& 4-CVD & 103 \\
& 5-CVD & 103 \\
& 6-CVD & 102 \\
& & \\
PM HOT ISOSTATIC & Hiped-1 & 88 \\
PRESSURE & Hiped-2 & 87 \\
& Hiped-3 & 87 \\
& Hiped-4 & 88 \\
& Hiped-5 & 87 \\
& Hiped-6 & 89 \\
& Hiped-7 & 89 \\
& Hiped-8 & 89 \\
& Hiped-9 & 87 \\
& Hiped-10 & 88 \\
\hline
\end{tabular}




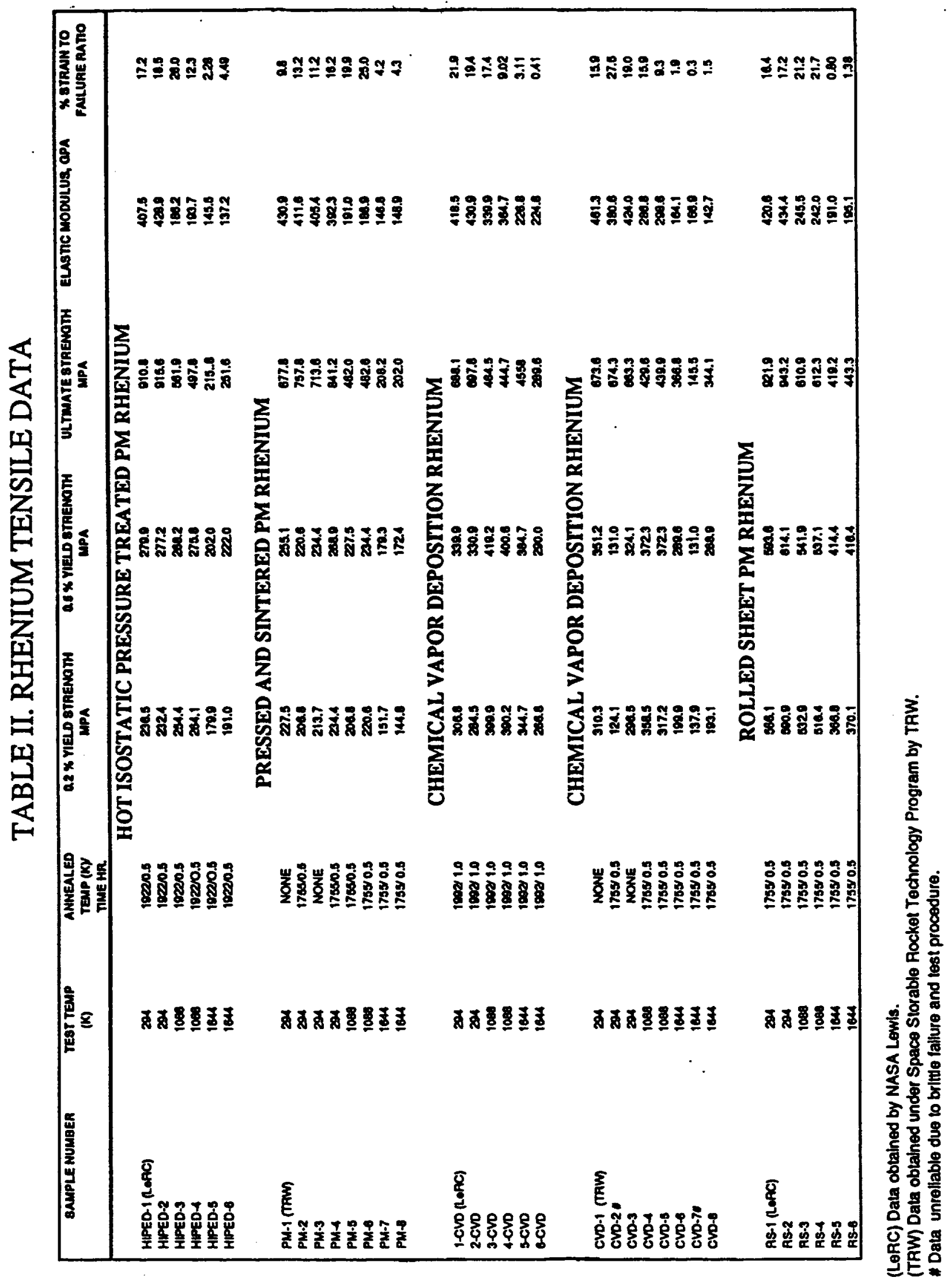


TABLE III. RHENIUM CREEP DATA

\begin{tabular}{|l|l|l|l|}
\hline SAMPLE & TEMPERATURE $(K)$ & $\begin{array}{l}\text { STRESS MPa } \\
\text { TENSIONCOMPRESSION }\end{array}$ & \% STRAN \\
\hline $\begin{array}{l}\text { CHEMICAL VAPOR } \\
\text { DEPOSITION }\end{array}$ & & & \\
\hline CVD-15 & 1922 & 27.5 & 0.22 \\
\hline CVD-16 & 1922 & 27.5 & 0.24 \\
\hline $\begin{array}{l}\text { PM PRESSED AND } \\
\text { SINTERED }\end{array}$ & & & \\
\hline PM-16 & 1922 & 27.5 & \\
\hline PM-17 & 1922 & 27.5 & 3.60 \\
\hline PM-18 & 1922 & 27.5 & 1.75 \\
\hline PM-19 & 1922 & 27.5 & 1.17 \\
\hline
\end{tabular}

TABLE - IV. LOW CYCLE FATIGUE FOR RHENIUM

\begin{tabular}{|c|c|c|c|}
\hline SAMPLE \# & TEMPERATURE (K) & $\begin{array}{l}\text { STRESS MPa } \\
\text { TENSIONCOMPRESSION }\end{array}$ & $\begin{array}{l}\text { CYCLES } \\
\text { COMPLETED }\end{array}$ \\
\hline $\begin{array}{l}\text { Chamieal Vapor Deposttion } \\
\text { CVDe }\end{array}$ & RT & $151.7 \pi 151.7$ & 100 \\
\hline CVD-10 & RT & $151.7 / 151.7$ & 100 \\
\hline CVo-11 & 1088 & $275.8 / 1793$ & FALED ON IST CYCLE \\
\hline CVD-12 & 1088 & $275.8 / 137.9$ & 100 \\
\hline CVD-13 & 1088 & $275.8 / 137.9$ & 11 \\
\hline cra-14 & 1088 & 275.8/137.9 & 12 \\
\hline CVD-15 & 1644 & 137.968 .9 & 85 \\
\hline CVD-16 & 1644 & $137.9 / 68.9$ & 37 \\
\hline $\begin{array}{l}\text { PII Prosend and Sintared } \\
\text { PII- }\end{array}$ & RT & $206.9 / 206.9$ & 100 \\
\hline$P M-10$ & RT & $189.6 / 189.6$ & 100 \\
\hline PU-11 & 1088 & $193.0 / 193.0$ & 100 \\
\hline P1H-12 & 1088 & $206.8 / 206.8$ & 100 \\
\hline PI-13 & 1644 & $137.9 / 137.9$ & 23 \\
\hline PI-14 & 1644 & $100.4 / 103.4$ & 100 \\
\hline PM-15 & 1644 & $103.4 / 103.4$ & 100 \\
\hline $\begin{array}{l}\text { PII Hot leostatic Proseure } \\
\text { HIPED-7 }\end{array}$ & 1088 & $137.9 / 68.9$ & 103 \\
\hline HIPEDA & 1088 & $127.6 / 62.1$ & $20^{\circ}$ \\
\hline HIPED-9 & 1644 & 131.062 .1 & 100 \\
\hline HIPED-10 & 1644 & 137.9168 .9 & 100 \\
\hline
\end{tabular}

- Sample was accidentally loaded to $248.2 \mathrm{MPa}$ in a pretest run and exhibired a plastic deformation of 1.2 percent when removed. The sample was also werped in the width direction due to stress relieving during the annealing cycte. 


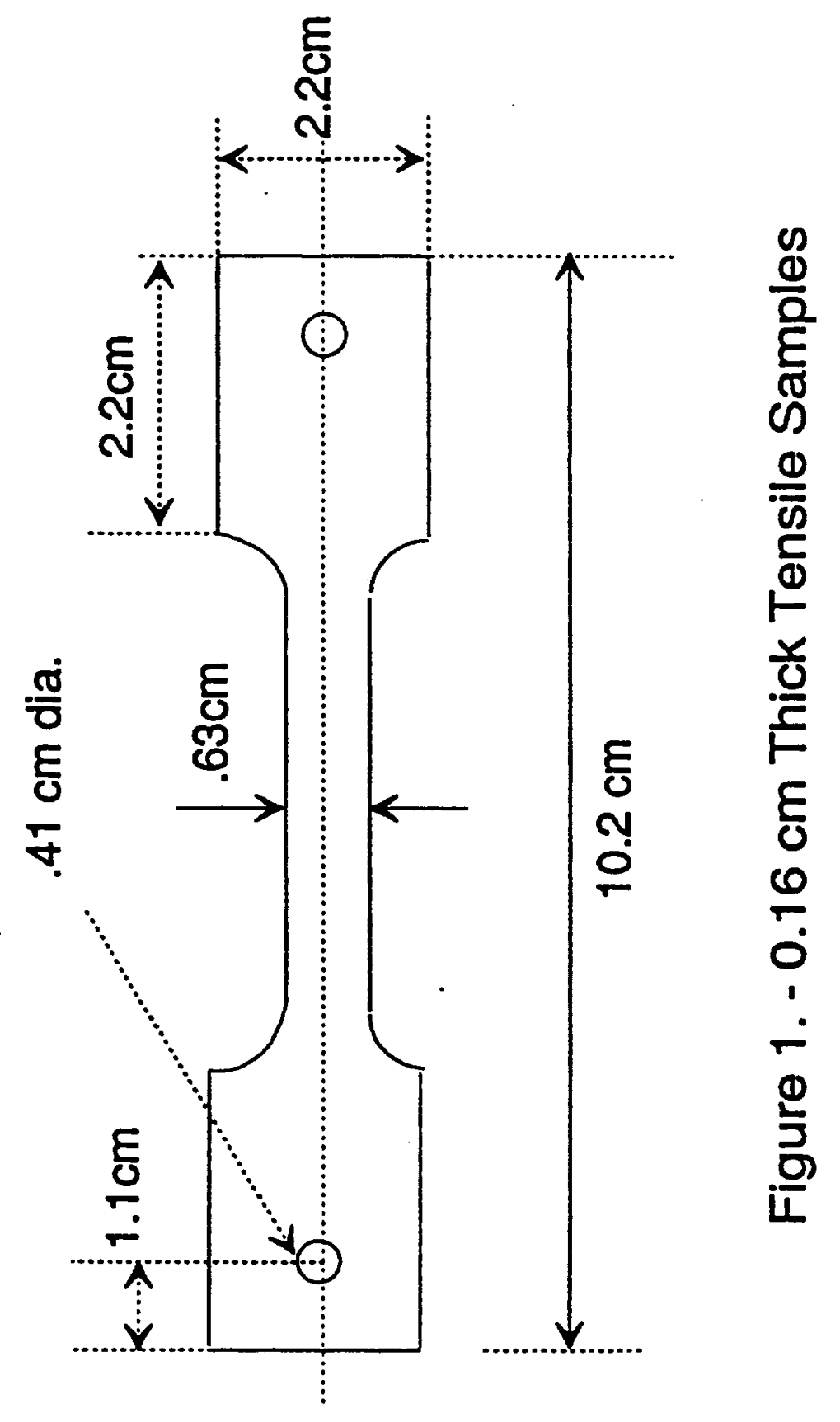




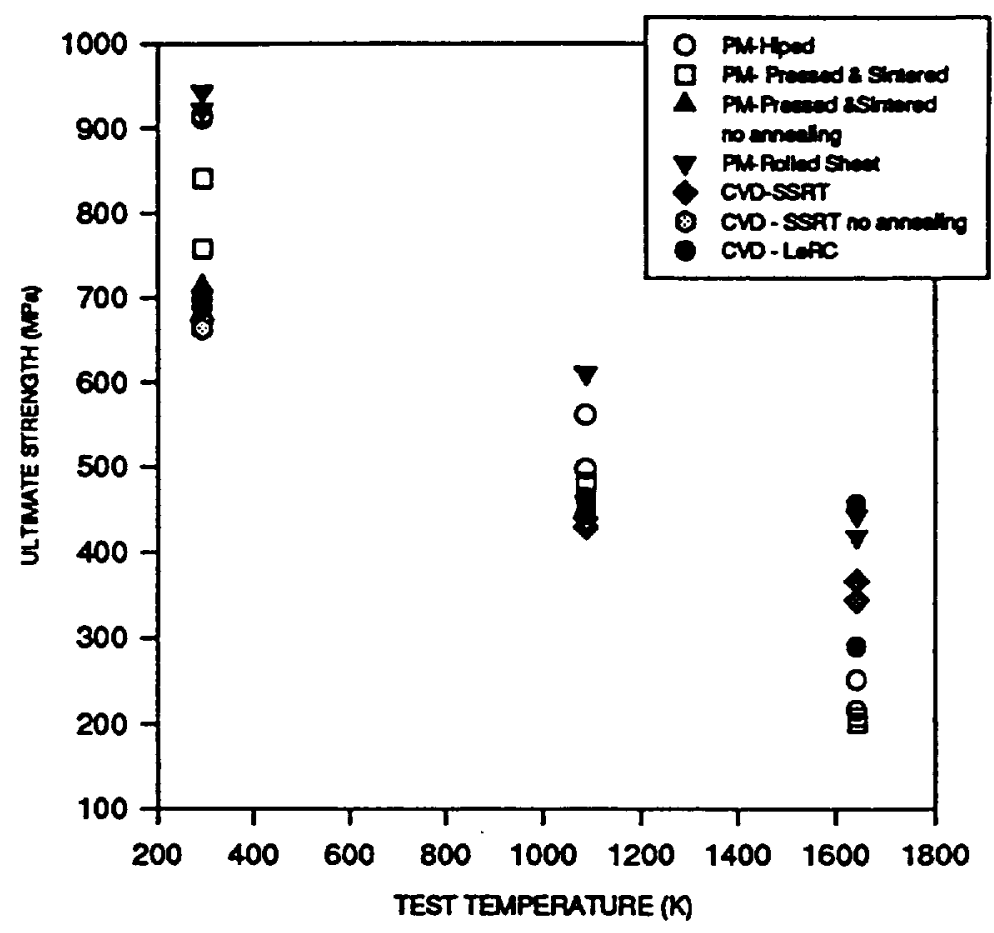

Fgure 2-2. RHENUL ULTHATE STRENGTH VS TEMPERATURE (K)

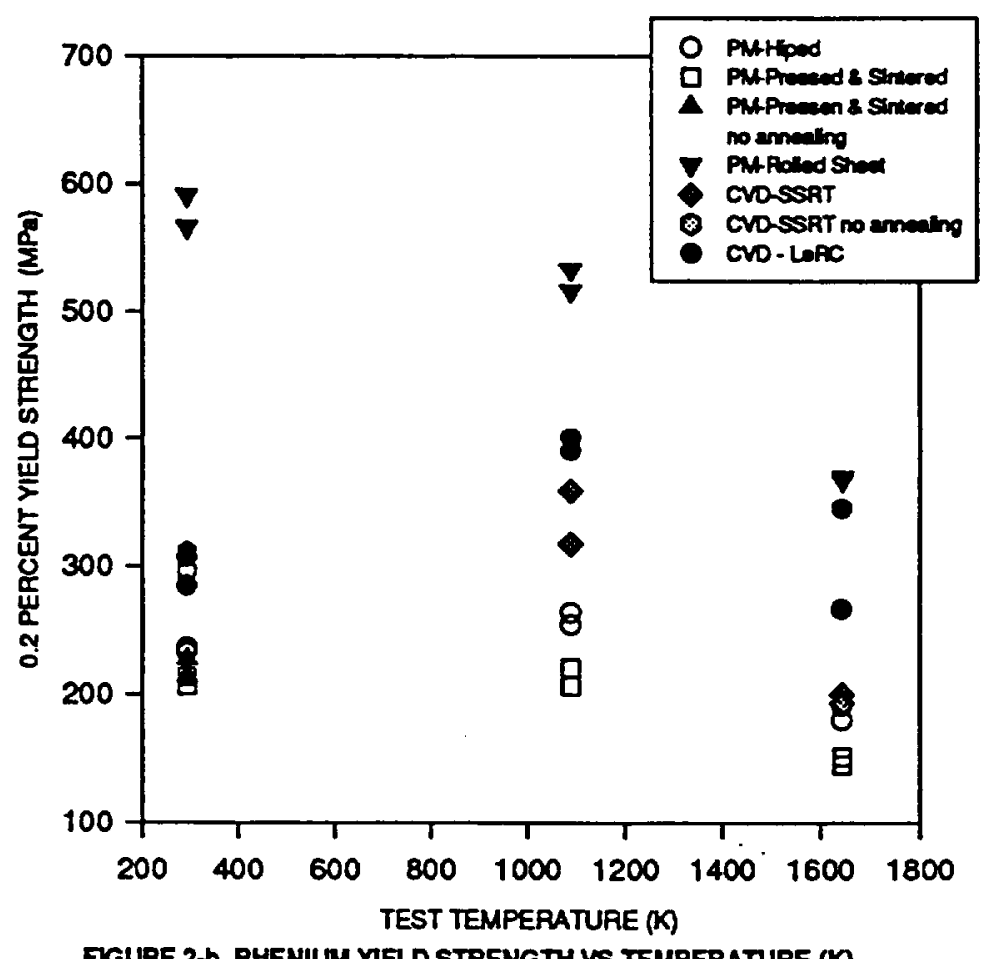

FGURE 2-b. RHENIUM VIELD STRENGTH VS TEMPERATURE (K)

FIGURE 2. ULTIMATE AND YIELD STRENGTH VS TEMPERATURE (K) 


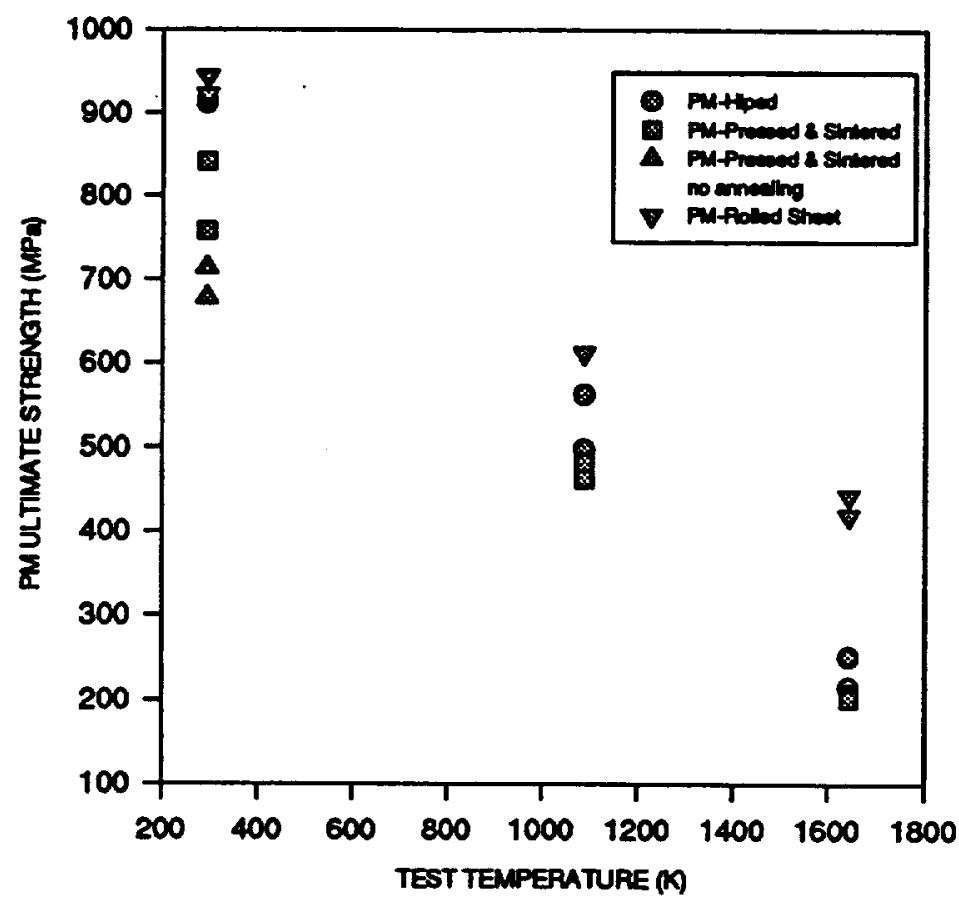

FGUFE 3e PU RHENUM ULTMATE STRENGTH VS TEMPERATURE (K)

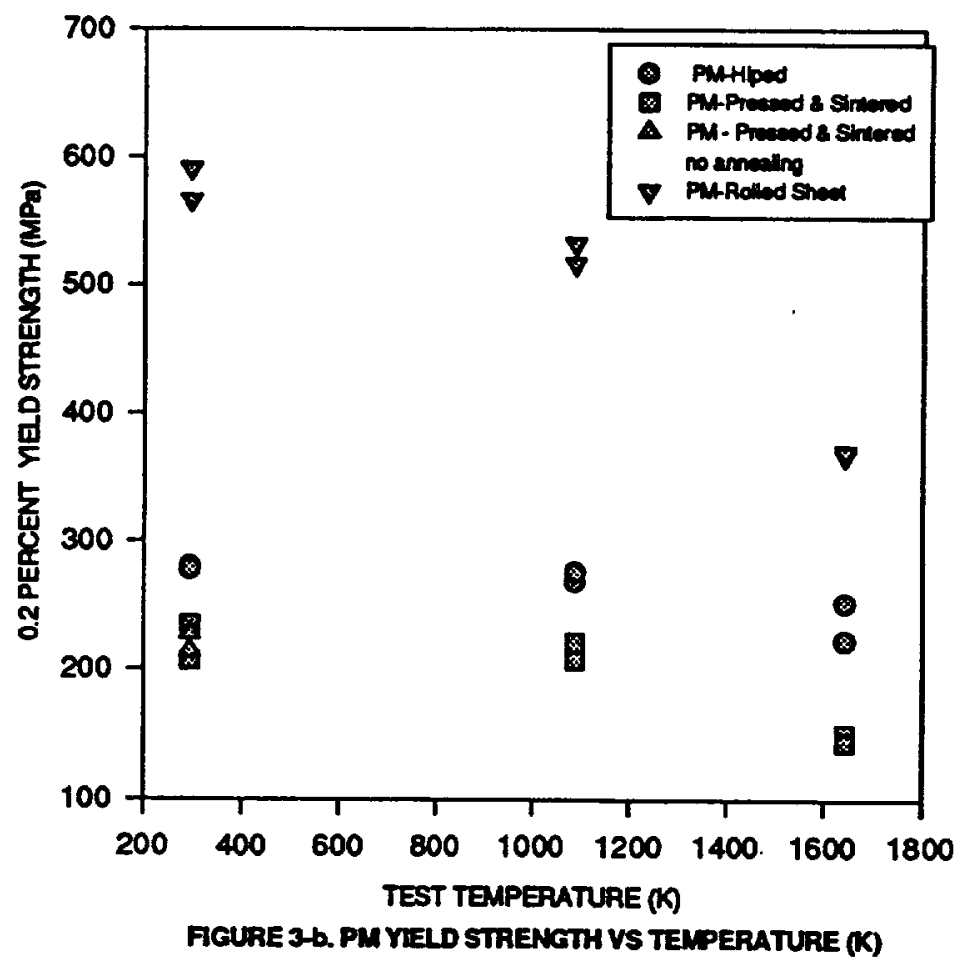

FIGURE 3. PM ULTMMATE AND YIELD STRENGTH VS TEMPERATURE (K) 


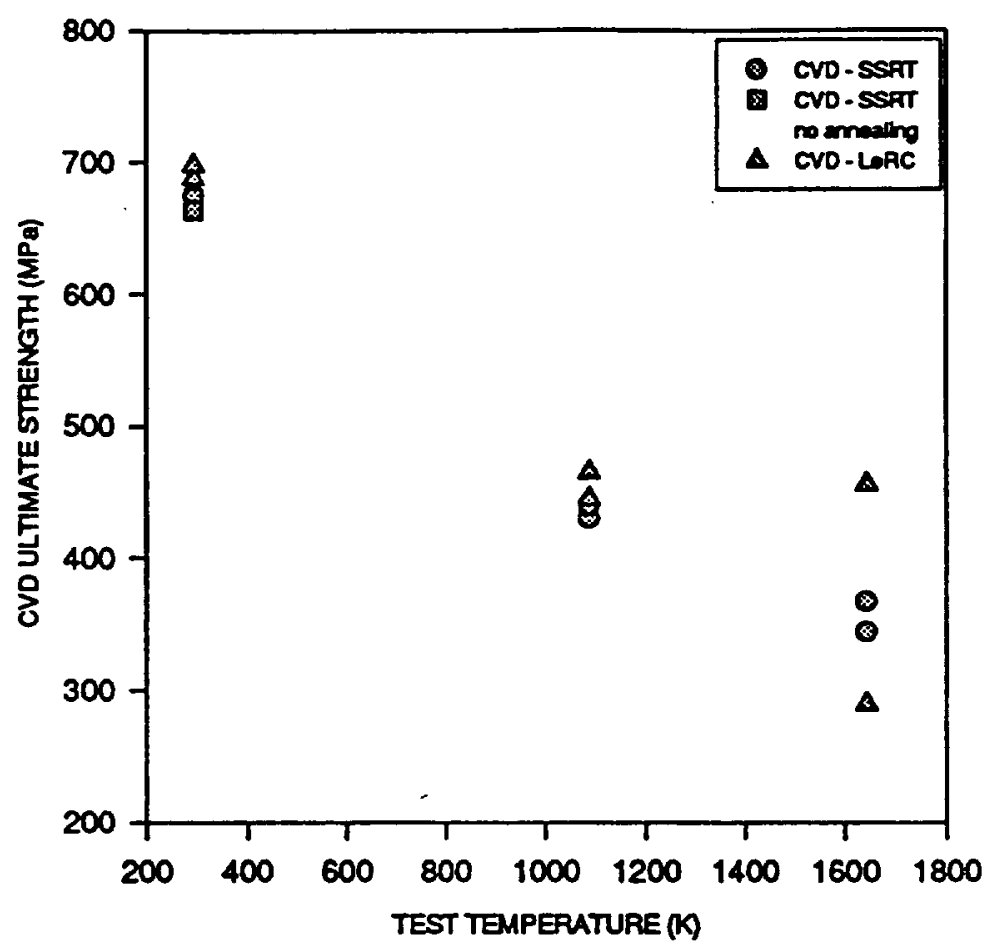

FGUFE 4E CVD ULTMATE STRENGTH VS TEMPERATURE (K)

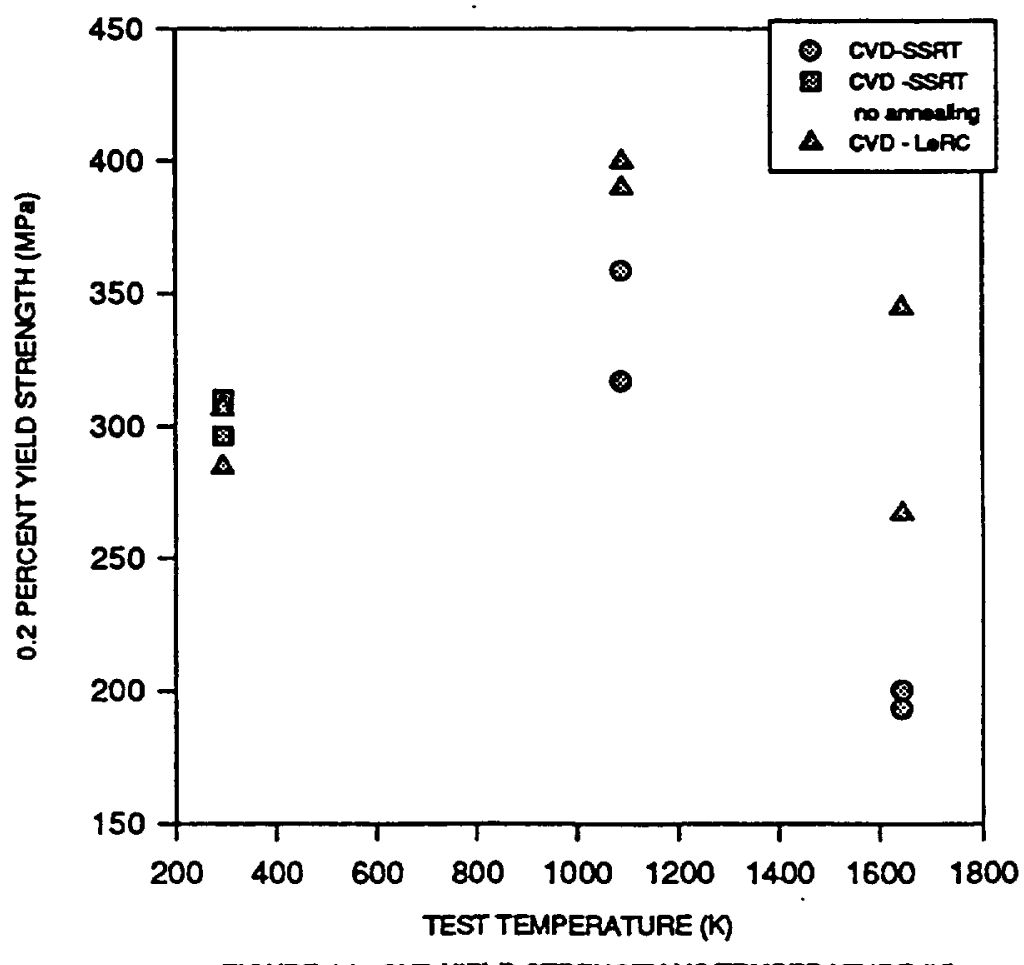

FIGURE 4- $b$ CVD YIELD STRENGTH VS TEMPERATURE $(K)$

FIGURE 4. CVD ULTIMATE AND YIELD STRENGTH VS TEMPERATURE (K) 

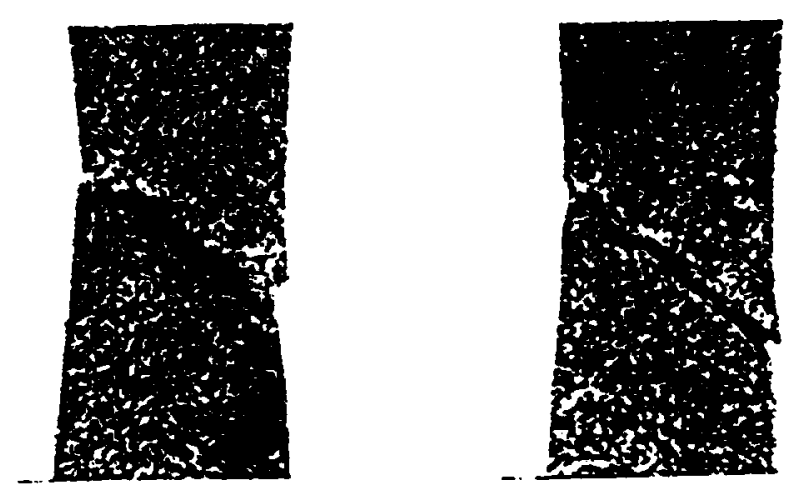

PM rolled sheet
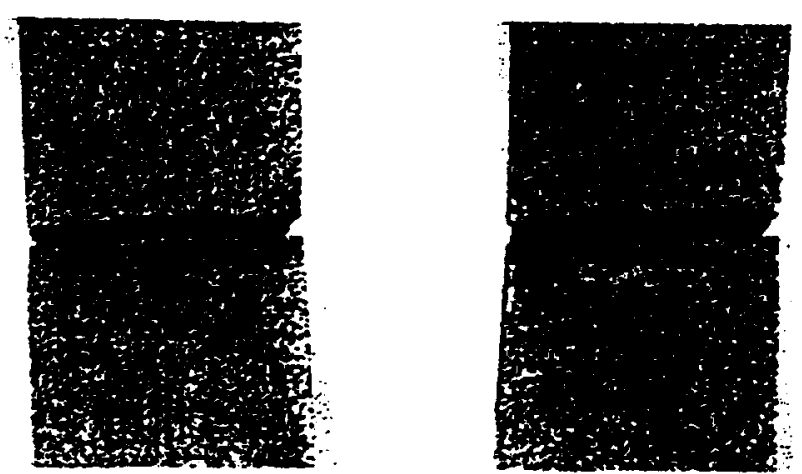

PM HIP rhenium
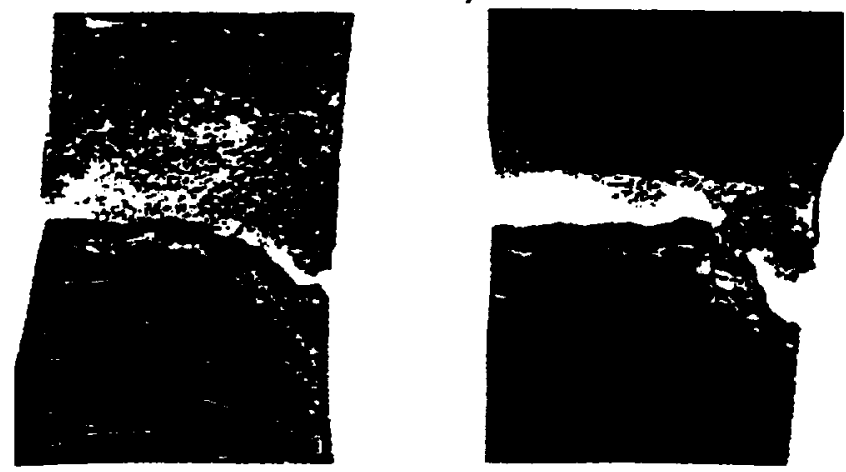

CVD rhenium

Figure 5. Typical tensile breaks for tested materials 


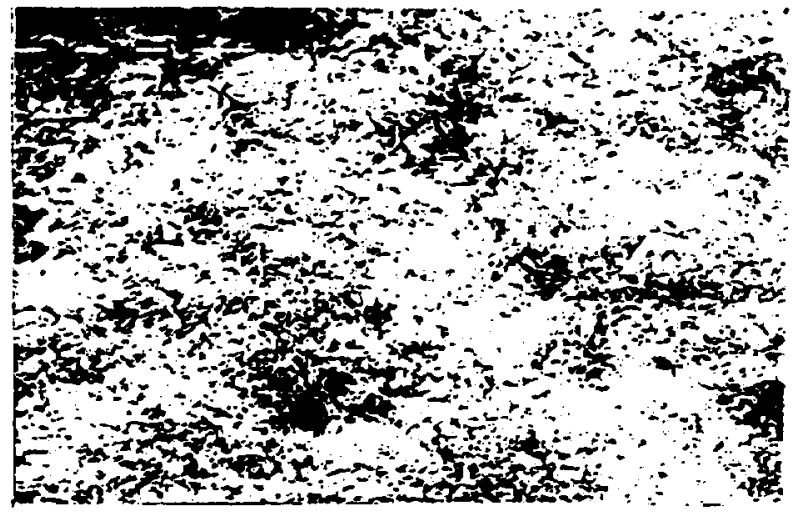

Room Temperature HIP Material

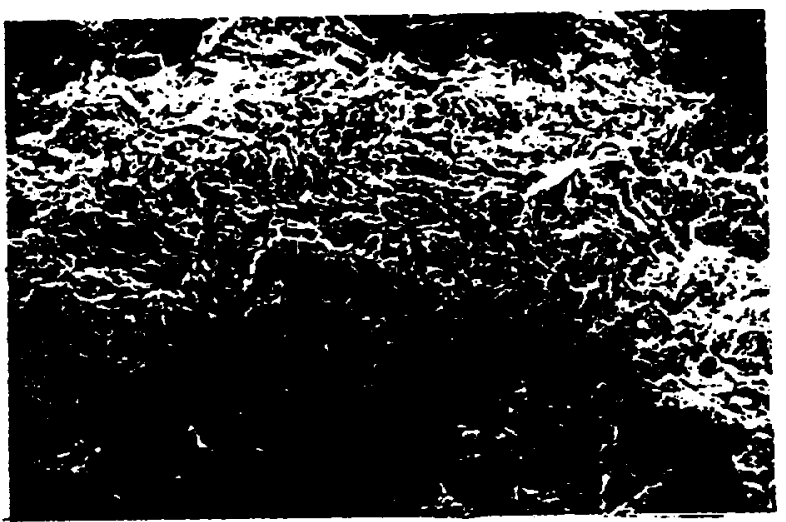

Room Temperature Rolled Sheet

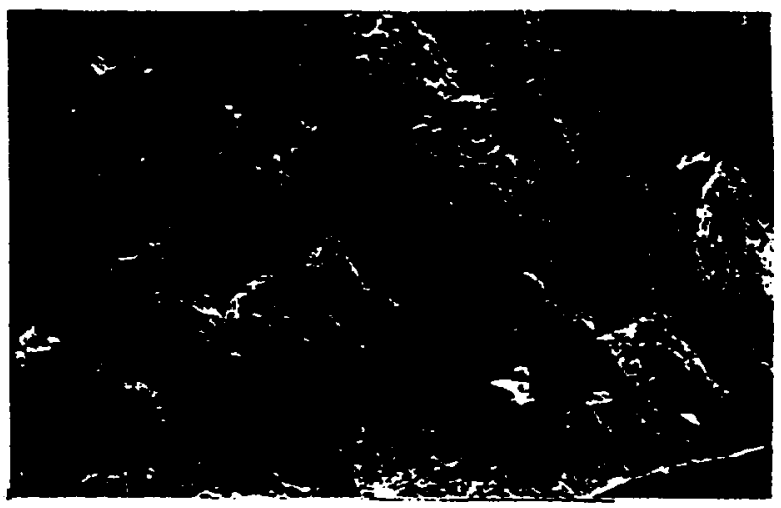

Room Temperature CVD

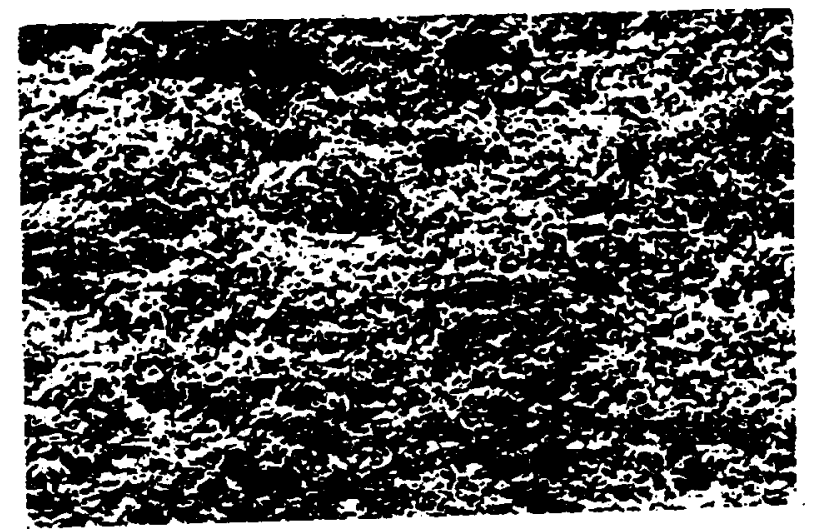

1644 K HIP Material

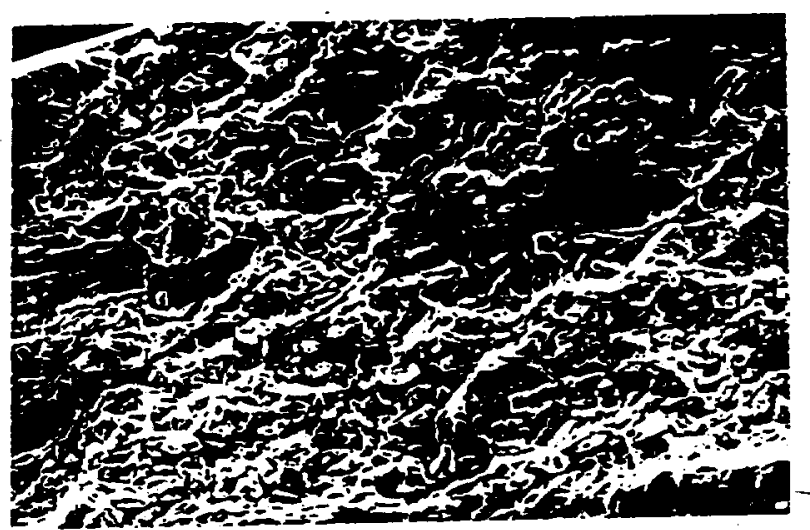

1644 K Rolled Sheet

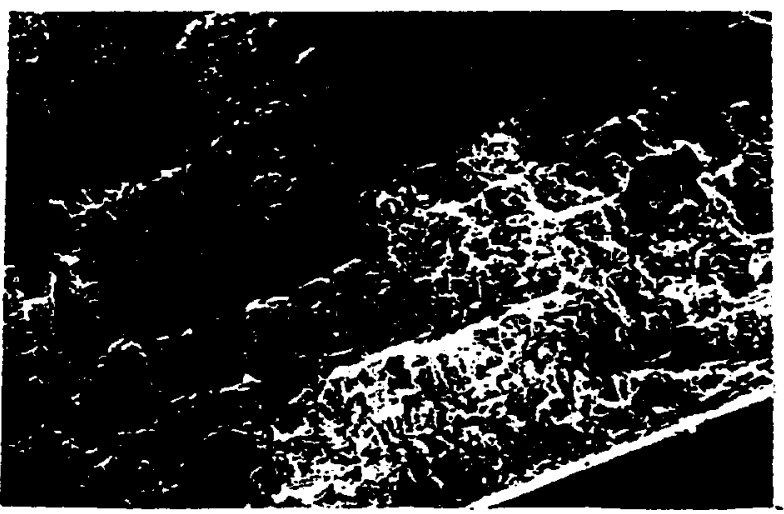

1644 K CVD

Figure 6.- Comparison of 60x electron microscope photographs of PM HIP, PM rolled sheet and CVD rhenium at room temperature and $1644 \mathrm{~K}$. 


\begin{tabular}{|c|c|c|c|c|}
\hline \multicolumn{3}{|c|}{ REPORT DOCUMENTATION PAGE } & & $\begin{array}{l}\text { Form Approved } \\
\text { OMB No. 0704-0188 }\end{array}$ \\
\hline \multicolumn{5}{|c|}{ 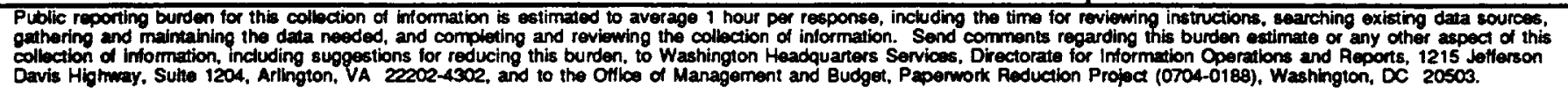 } \\
\hline 1. AGENCY USE ONLY (Leave blank) & \multicolumn{2}{|l|}{$\begin{array}{l}\text { 2. REPOAT DATE } \\
\text { September } 1995\end{array}$} & \multicolumn{2}{|c|}{$\begin{array}{l}\text { 3. REPORT TYPE AND DATES COVERED } \\
\text { Technical Memorandum }\end{array}$} \\
\hline \multicolumn{3}{|c|}{$\begin{array}{l}\text { 4. TITLE AND SUPTTLE } \\
\text { Rhenium Material Properties }\end{array}$} & \multicolumn{2}{|c|}{ 5. FUNDING NUMBERS } \\
\hline \multicolumn{3}{|l|}{$\begin{array}{l}\text { 6. AUTHOR(S) } \\
\text { James A. Biaglow }\end{array}$} & \multicolumn{2}{|c|}{ WU-232-02-03 } \\
\hline \multicolumn{3}{|c|}{$\begin{array}{l}\text { 7. PERFORIMNG OAGANIZATION NAME(S) AND ADDRESS(ES) } \\
\text { National Aeronautics and Space Administration } \\
\text { Lewis Research Center } \\
\text { Cleveland, Ohio } 44135-3191\end{array}$} & \multicolumn{2}{|c|}{$E-9878$} \\
\hline \multicolumn{3}{|c|}{$\begin{array}{l}\text { 9. SPONSOFINGMONITOAING AGENCY NAME(S) AND ADDRESS(ES) } \\
\text { National Aeronautics and Space Administration } \\
\text { Washington, D.C. } 20546-0001\end{array}$} & 10. St & $\begin{array}{l}\text { NSOAINGMONITOPING } \\
\text { ENCY REPORT NUMBER } \\
\text { SA TM-107043 } \\
\text { LA-95-2398 }\end{array}$ \\
\hline \multicolumn{5}{|c|}{$\begin{array}{l}\text { 11. SUPPLEMENTARY NOTES } \\
\text { Responsible person, James A. Biaglow, organization code } 5330 \text {, (216) 977-7480. }\end{array}$} \\
\hline $\begin{array}{l}\text { 12. DISTAIBUTIONAVAILABILT } \\
\text { Unclassified - Unlimited } \\
\text { SubjectCategories } 26,27 \\
\text { This publication is available }\end{array}$ & $\begin{array}{l}\text { STATENENT } \\
20 \text {, and } 29 \\
\text { on the NASA Center for Aerospace }\end{array}$ & ormation & \multicolumn{2}{|c|}{ 12b. DISTRIBUTION CODE } \\
\hline \multicolumn{5}{|c|}{$\begin{array}{l}\text { Tensile data were obtained from four different types of rhenium at ambient and elevated temperatures. The four types of } \\
\text { rhenium included chemical vapor deposition (CVD) and three powder metallurgy (PM) types, i.e., rolled sheet and } \\
\text { pressed and sintered bars, with and without hot isostatic pressure (HIP) treatment. Results revealed a wide range of values } \\
\text { with ultimate strengths at ambient temperatures varying from } 663 \mathrm{MPa} \text { for CVD rhenium to } 943 \mathrm{MPa} \text { for rolled sheet. A } \\
\text { similar spread was also obtained for material tested at } 1088 \mathrm{~K} \text { and } 1644 \mathrm{~K} \text {. The wide variance observed with the different } \\
\text { materials indicated that the rhenium manufacturing process, material composition and prior handling strongly dictated its } \\
\text { properties. In addition to tensile properties, CVD, pressed and sintered material and HIP rhenium successfully completed } \\
100 \text { cycles of low cycle fatigue. Creep data were also obtained showing that CVD and pressed and sintered rhenium } \\
\text { could sustain five hours of testing under a tension of } 27.5 \mathrm{MPa} \text { at } 1922 \mathrm{~K} \text {. }\end{array}$} \\
\hline \multirow{2}{*}{\multicolumn{2}{|c|}{$\begin{array}{l}\text { 14. SUBJECT TERMS } \\
\text { Rhenium material; Material properties }\end{array}$}} & & & $\begin{array}{c}\text { 15. NUMBER OF PAGES } \\
17\end{array}$ \\
\hline & & & & $\begin{array}{r}\text { 16. PRICE CODE } \\
\mathrm{A} 03\end{array}$ \\
\hline $\begin{array}{l}\text { 17. SECURTY CLASSIFICATION } \\
\text { OF REPORT } \\
\text { Unclassified }\end{array}$ & $\begin{array}{l}\text { 18. SECURTY CLASSIFICATION } \\
\text { OF THIS PAGE } \\
\text { Unclassified }\end{array}$ & $\begin{array}{l}\text { 19. SEC } \\
\text { OF }\end{array}$ & ATION & 20. LIMITATKON OF ABSTRACT \\
\hline
\end{tabular}

